УДК 342.9

DOI https://doi.org/10.32849/2663-5313/2020.4.33

Павло Яковлев, канд. юрид. наук, докторант кафедри державно-правових дисииплін Харківського національного університету імені В.Н. Каразіна

\title{
ФОРМИ ДЕРЖАВНОГО РЕГУЛЮВАННЯ У СФЕРІ ЗАБЕЗПЕЧЕННЯ ІНФОРМАЦЙНОЇ БЕЗПЕКИ УКРАЇНИ
}

У статті розкривається зміст і пропонується класифікація правових форм державного регулювання забезпечення інформачійної безпеки України. На основі аналізу доктринальних поглядів на зміст категорії «форма адміністративно-правового регулювання» запропоновано під правовими формами державного регулювання у сфері забезпечення інформачійної безпеки розуміти визначені чинним законодавством види юридично значущої діяльності уповноважених суб'єктів державного управління у сфері регулювання прочесів запобігання, припинення й ліквідаиії наслідків посягання на інформаційну безпеку України, застосування яких тягне за собою зміну правового становища учасників відносин у сфері забезпечення інформаційної безпеки або впливає на начіональне інформачійне середовище.

Запропоновано правові форми нормативних і індивідуальних актів з питань реалізації державної політики у сфері забезпечення інформачійної безпеки й учинення інших юридично значущих дій, які пов'язані з інформачійними відносинами. Наведено характеристику кожної з форм. Акцентовано увагу на тому, що серед можливих заходів юридичного впливу на сферу забезпечення інформачійної безпеки адміністративна відповідальність посідає одне з головних місиь поряд з відповідальністю кримінальною, оскільки охоплює доволі значний обсяг суспільних відносин в інформачійній сфері.

Обгрунтовано, що практична ефективність правових форм державного регулювання у сфері інформаційної безпеки залежить від рівня професійної підготовки прачівників органів державного управління, до компетениї яких належить здійснення владних дій з метою забезпечення інформаиійної безпеки України. Зауважено, що зміст правових форм державного регулювання у сфері забезпечення інформаційної безпеки має завжди відповідати рівню технічного розвитку засобів, методів і способів посягання на національне інформачійне середовище.

Ключові слова: Україна, інформація, правові форми державного регулювання, функції,державна політика, інформаційна безпека, інформаційний суверенітет, адміністративна відповідальність.

Постановка проблеми. В умовах окупації Автономної Республіки Крим, а також тривалої напруженості військово-політичної ситуації у східних областях України актуальним питанням державного розвитку залишається ефективність державного управління у сфері забезпечення інформаційної безпеки держави. Недоброзичливі посягання на національне інформаційне середовище України останніми роками стали чинником виникнення деструктивних явищ в українському соціумі. Руйнівний вплив цілеспрямованого застосування інформаційних технологій, розповсюдження дезінформації серед населення, технічне пошкодження об'єктів національної інформаційної інфраструктури $€$ чинниками, які порушують стабільний режим функціонування державних інституцій, наносять значну шкоду гуманітарній сфері життедіяльності суспільства. За таких умов система державного управління має напрацювати ефективні форми правового владного регулювання процесів поперед- ження, припинення й ліквідації наслідків загроз і ризиків у сфері інформаційної безпеки. Разом з цим, права й свободи громадян у сфері збору й використання інформації мають бути дотримані відповідно до загальноприйнятих міжнародних і європейських стандартів. В зазначеному аспекті перед доктриною адміністративного права постає важливе науково-практичне завдання, яке полягає в обгрунтуванні сутності основних правових форм державного регулювання у сфері забезпечення інформаційної безпеки України.

Проблематиці забезпечення інформаційної безпеки в Україні присвячено значну кількість наукових праць, які стали інформаційним підгрунтям для формування ідейного змісту статті. Зокрема було використано праці таких дослідників: В.Б. Авер'янова, Ю.П. Битяка, В.В. Богуцького, В.М. Гаращука, В.В. Зуя, В.К. Колпакова, В.М. Соловйова та інших. Разом з тим, наукових розробок, присвячених аспектам 
адміністративно-правового забезпечення діяльності системи державного управління в напрямі забезпечення інформаційної безпеки України, є незначна кількість. Отже, доцільно доповнити напрацювання вітчизняної доктрини адміністративного права розробленням відповідних питань, які раніше замало потрапляли в поле зору науковців.

Метою статті $є$ наведення класифікації й визначення сутності основних правових форм державного регулювання у сфері забезпечення інформаційної безпеки України.

Виклад основного матеріалу. Державне регулювання є складним соціальним, правовим і політичним феноменом. Регулювання суспільних явищ і процесів передбачає приведення поведінки суб'єктів і їх утворень до дотримання вимог правових норм, обмеження поведінки певними дозволами і заборонами [1, с. 27]. Державне регулювання завжди здійснюється шляхом застосування права у межах управлінського процесу. Водночас специфіка сфери суспільних відносин, яка підлягає регулюванню, обумовлює вибір оптимального юридичного інструментарію з урахуванням дотримання стандартів прав людини й громадянина. Сфера забезпечення інформаційної безпеки є важливою, адже попре нормативну невизначеність змісту категорії «інформаційна безпека» чинна Конституція України від 28 червня 1996 р. визначає, що забезпечення інформаційної безпеки $\epsilon$ найважливішою функцією держави і справою всього українського народу [2]. Втілюючи це положення в життя, держава формує окремий напрям внутрішньої політики, заходи якої спрямовані на забезпечення інформаційної безпеки України.

У ракурсі юридичного погляду на правові форми державного регулювання у сфері забезпечення інформаційної безпеки України слід відзначити, що їхній зміст безпосередньо визначається нормами адміністративного права, яке регулює владний вплив на суспільні відносини й процеси [3]. Відповідно, правова форма державного регулювання також передбачає нормативне впорядкування конкретизованого владного впливу на суспільні відносини задля реалізації завдань і функцій публічної адміністрації.

Прямуючи до визначення категорії «правова форма державного регулювання», слід зауважити, що ця категорія є похідною від поняття «форми адміністративно-правового регулювання». Представники української юридичної науки, визначаючи зміст зазначеної категорії, у цілому мають схожі погляди на тлумачення дефініції «форма адміні- стративно-правового регулювання». Так, Ю.П. Битяк пропонує під «формою адміністративно-правового регулювання» розуміти зовнішній вияв дій, що здійснюється органами виконавчої влади для реалізації поставлених перед ними завдань [4, с. 115]. О.М. Бандурка та К.Л. Бугайчук пропонують розуміти під формою адміністративно-правового регулювання зовнішній вияв управлінської діяльності за конкретних умов [5, с. 185] Своєю чергою такі науковці, як Т.О. Коломоєць, В.К. Колпаков, Є.В. Валькова у визначення змісту категорії форми адміністративно-правового регулювання покладають ідею цілепокладання і наголошують на тому, що це волевиявлення суб'єкта управління, що здійснюється у межах його компетенції для досягнення конкретної мети або виконання завдання [6, с. $54 ; 7$, с. $199 ; 8$, с. 61$]$.

Форми адміністративно-правового регулювання у сфері забезпечення інформаційної безпеки України за правовими наслідками класифікуємо на правові й неправові (організаційні). Правові форми тягнуть за собою юридичні наслідки й здатні змінювати правове становище суб'єктів, які є учасниками відносин у сфері інформаційної безпеки, або змінювати саму інформаційну сферу. Своєю чергою організаційні форми такого навантаження не несуть, мають забезпечувальний характер щодо протікання управлінських процесів у сфері забезпечення інформаційної безпеки.

Беручи до уваги особливості доктринального розуміння зазначених категорій, а також враховуючи специфіку державного управління у сфері забезпечення інформаційної безпеки держави, під правовими формами державного регулювання у сфері забезпечення інформачійної безпеки пропонуємо розуміти визначені чинним законодавством види юридично значущої діяльності уповноважених суб'єктів державного управління у сфері регулювання прочесів запобігання, припинення й ліквідачї̈ наслідків посягання на інформачійну безпеку Украйни, застосування яких тягне за собою зміну правового становища учасників відносин у сфері забезпечення інформачійної безпеки або впливає на начіональне інформачійне середовище. Якщо більш конкретизовано, то правовими формами $\epsilon$ видання нормативних та індивідуальних актів 3 питань реалізації державної політики у сфері забезпечення інформаційної безпеки й учинення інших юридично значущих дій, які пов’язані з інформаційними відносинами.

Основне призначення нормативних та індивідуальних актів у сфері інформаційної безпеки полягає у створенні системи норм, які закладають правовий режим 
забезпечення інформаційної безпеки як соціально-державної цінності й деталізують загальні положення законодавства щодо протидії інформаційним загрозам. Так, норми Закону України «Про національну безпеку України» від 21 червня 2018 р. встановлюють, що забезпечення інформаційної безпеки $є$ складовою компонентою національної безпеки [9]. Відповідно суб'єкти, які уповноважені здійснювати державне управління у сфері інформаційної безпеки видають підзаконні нормативні й індивідуальні акти задля стратегічного й оперативного впливу на процеси функціонування національного інформаційного простору.

Видання нормативних актів як правова форма державного управління у сфері забезпечення інформаційної безпеки має певні особливості. Зокрема нормативні акти можна класифікувати як акти універсальної дії, спеціальної дії, локальної дії. Акти загальної дії поширюють регуляторний вплив норм на всі органи й установи, яких залучено до реалізації державної політики у сфері забезпечення інформаційної безпеки; спеціальні акти поширюються лише на систему органів (Служба безпеки України) й конкретні установи (Міністерство закордонних справ); локальні мають регулятивне значення на рівні органу або установи, що уповноважена здійснювати спектр завдань із забезпечення інформаційного суверенітету держави. Яскравим прикладом $є$ Рішення Ради національної безпеки і оборони Украіни від 29 грудня 2016 р. «Про Доктрину інформаційної безпеки України», яку було введено в дію Указом Президента України від 25 лютого 2017 р. [10].

Зазначений вище документ створює адміністративно-правову основу для виконання низки важливих завдань державного управління у сфері забезпечення інформаційної безпеки. У його положеннях наведено основні загрози інформаційній безпеці України; визначено перелік органів державної влади, які на основі співробітництва розробляють і реалізовують першочергові завдання у сфері забезпечення інформаційної безпеки держави, зокрема це Міністерство інформаційної політики України (до реорганізації у 2019 р.), Міністерство закордонних справ, Міністерство оборони, Міністерство культури, Служба безпеки України, розвідувальні органи, Державна служба спеціального зв'язку та захисту інформації; сформульовано пріоритетні напрями державної політики кожного з наведених вище відомств; установлено нормативні засади здійснення координації різними відомствами державної політики в означеній сфері
(Рада національної безпеки і оборони України як дорадча інституція Президента України й Кабінет Міністрів України як орган, що забезпечує здійснення загальної інформаційної політики в державі); на суб'єкти державного управління у сфері інформаційної безпеки покладаються у необхідних випадках певні спеціальні обов'язки або надаються спеціальні повноваження (наприклад, на Службу безпеки України Доктриною інформаційної безпеки покладено здійснення моніторингу спеціальними методами й способами вітчизняних та іноземних засобів масової інформації й мережі Інтернет з метою виявлення загроз національній безпеці України в інформаційній сфері) тощо. Разом з цим зазначимо, що на сьогодні в правовій системі України відсутні нормативні акти, які б чітко регламентували аспекти співробітництва суб'єктів державного управління, які уповноважені виконувати функції забезпечення інформаційної безпеки держави.

Правові акти індивідуальної дії у сфері забезпечення інформаційної безпеки розраховані на врегулювання конкретної ситуації у сфері забезпечення інформаційної безпеки й або розповсюджують свою дію на конкретні суб'єкти, або об'єктом їхнього регулювання стає певний режим зберігання, використання чи захисту самої інформації. Як приклад можна навести положення Закону України «Про державну таємницю» від 21 січня 1994 р. № 3855-XII, яке регламентує видання наказу про призначення осіб на посади заступників керівників з питань режиму, начальників режимно-секретних органів i їхніх заступників або наказу про покладення на окремого працівника обов'язків щодо забезпечення режиму секретності [11].

Не менш важливим є вчинення інших юридично значущих дій у сфері забезпечення інформаційної безпеки України, спрямоване на упорядкування дій, які пов'язані зі збиранням, використанням або розповсюдженням інформації. Юридично значущі дії розглядаються як діяльність, що здійснюється на підставі законів та інших підзаконних нормативних актів і спрямована на виникнення певних юридичних наслідків (до таких дій віднесено державну реєстрацію, видання офіційних документів, ліцензування, складання адміністративного протоколу) [12, с. 178]. Прикладом є віднесення інформації до такої, що має режим державної таємниці. Так, Наказ Служби безпеки України «Про затвердження Зводу відомостей, що становлять державну таємницю» від 12 серпня 2005 р. № 440 встановлює, що Служба безпеки має монопольне право формувати Звід відомостей, що становлять 
державну таємницю та здійснювати реєстрацію відповідної інформації у Зводі [13]. Водночас відповідна інформація має індивідуальні ознаки та є особливою з точки зору недопущення загального її публічного оприлюднення. У такому разі внесення певної інформації до Зводу є юридичним фактом, який обумовлює виникнення, зміну або припинення конкретних адміністративно-правових відносин у сфері захисту інформації, що становить державну таємницю. Така юридично значуща дія $є$ наслідком прийняття управлінського рішення.

Окрім зазначеного вище, важливим прикладом юридично значущих дій є складання протоколів про адміністративні правопорушення, які посягають на інформаційну інфраструктуру України й режим використання інформації загалом. Складення протоколу $є$ формальною підставою для того, щоб винну особу було притягнуто до адміністративної відповідальності. Серед можливих заходів юридичного впливу на сферу забезпечення інформаційної безпеки, адміністративна відповідальність посідає одне 3 головних місць поряд з відповідальністю кримінальною, оскільки охоплює доволі значний обсяг суспільних відносин в інформаційній сфері [14]. Єдиним кодифікованим законодавчим актом, який містить склади адміністративних правопорушень у сфері інформаційної безпеки й передбачає заходи адміністративної відповідальності за іiі порушення, $є$ Кодекс України про адміністративні правопорушення від 07 грудня 1984 р. [15].

Слід наголосити, що чинний Кодекс України про адміністративні правопорушення передбачає адміністративну відповідальність за посягання на інформаційні відносини в різних галузях, а саме в галузі охорони праці та здоров'я населення (ст. 41-3), у галузі охорони природи, використання природних ресурсів, охорони культурної спадщини (ст. ст. 53-2, 82-1, 82-3, 91-4, 92-1), галузі шляхового господарства та зв'язку (ст. ст. 116-3, 144, 145, 148), житлово-комунального господарства та благоустрою (ст. 149-1), галузі господарської діяльності та послуг (ст. 163-5, 163-9, 163-11, 164-6, 164-9, 166-4), галузі протидії корупції (172-8), установленого порядку управління (ст. ст. 184-2, 185-11, 186-3, 188-7, 188-31, 188-32, 188-35, 188-36, 188-37, 188-39, 211-2, 211-5, 2012-2, 212-3, 212-5, 212-6), здійснення народного волевиявлення й порядку його забезпечення (ст. ст. 212-7, 212-8, 212-9, 212-11, 212-13, 212-14). Адміністративна відповідальність виконує також роль своєрідного «гаранта» дотримання інформаційного правопорядку в державі.

\section{Висновки}

Проаналізовані вище правові форми державного регулювання у сфері забезпечення інформаційної безпеки України є багатоманітними за змістом і мають значний регуляторний потенціал, виступають чинником національної безпеки держави. Проте їхня ефективність на практиці значною мірою залежить від рівня професійної підготовки працівників органів державного управління, до компетенції яких належить здійснення владних дій 3 метою забезпечення інформаційної безпеки України. Крім цього зміст правових форм державного регулювання у сфері забезпечення інформаційної безпеки має завжди відповідати рівню технічного розвитку засобів, методів і способів посягання на національне інформаційне середовище. Відповідно, перспективним напрямом досліджень юридичної науки України є формування науково обгрунтованих пропозицій щодо оптимізації нормативної регламентації правових форм державного адміністрування у сфері забезпечення інформаційної безпеки з урахуванням організаційно-технічної складової.

\section{Список використаних джерел:}

1. Соловйов В.М. Поняття і сутність правового регулювання державного управління України. Університетські наукові записки. 2007. № 3. С. 27-33.

2. Конституція України : Закон України від 28 червня 1996 р. № 254к/96-ВР / Верховна Рада України. Відомості Верховної Ради України. 1996. № 30. Ст. 141.

3. Норми адміністративно-правового регулювання. Інтернет-сайт «Освіта Украӥни». URL: https://osvita.ua/vnz/reports/gov reg/17567/ (дата звернення 28.03.2020).

4. Адміністративне право : підручник / Ю.П. Битяк та ін. Харків : Право. 2010. 624 с.

5. Бандурка О.М., Бугайчук К.Л., Гуменюк А.А Адміністративне право України : підручник. Харків : Видавництво Національного університету внутрішніх справ, 2004. 480 с

6. Коломоєць Т.О., Гулевська Г.Ю. Адміністративне право України : навчальний посібник. Київ : Істина, 2007. 216 с.

7. Колпаков В.К., Кузьменко О.В. Адміністративне право України : підручник. Київ : Юрінком-інтер, 2003. $544 \mathrm{c}$.

8. Валькова Є.В. Форми адміністративно-правового регулювання у сфері охорони права інтелектуальної власності. Право $і$ безпека. 2012. № 5(47). С. 61-64.

9. Про національну безпеку України : Закон України від 21 червня 2018 р. № 2469-VIII. Відомості Верховної Ради України. 2018. № 31. Ст. 241.

10. Про рішення Ради національної безпеки і оборони України від 29 грудня 2016 р. «Про Доктрину інформаційної безпеки України» : Указ Президента України від 25 лютого 2017 р. № 47/217. 
Офіиійний вісник Президента Украйни. 2017. № 5. C. 15.

11. Про державну таємницю : Закон України від 21 січня 1994 р. № 3855-XII. Відомості Верховної Ради України. 1994. № 16. Ст. 93.

12. Аверьянов В.Б., Додин Е.В., Пахомов И.Н. Административное право Украины : учебник. Харьков : Одиссей, 2005. 880 с.

13. Про затвердження Зводу відомостей, що становлять державну таємницю : Наказ Служби безпеки України від 12 серпня 2005 р. № 440. Oфiиійний вісник України. 2005. № 34. С. 172.

14. Перун Т.С. Адміністративна відповідальність в системі заходів забезпечення інформаційної безпеки. Caŭm Aphd. URL: http://aphd.ua/ publication-358/ (дата звернення: 02.04.2020).

15. Кодекс України про адміністративні правопорушення : Закон України від 7 грудня 1984 р. № 8073-10. Відомості Верховної Ради УРСР. 1984. № 51. Ст. 1122.

In the article maintenance opens up and offered classification of legal forms of government control of providing of informative safety of Ukraine. On the basis of analysis of doctrine looks to maintenance of category "form of the administrative legal adjusting" it is suggested under the legal forms of government control in the field of providing of informative safety to understand certain a current legislation kinds legally meaningful activity of the authorized subjects of state administration in the field of adjusting of processes of warning, stopping and liquidation of consequences of trenching upon informative safety of Ukraine, application of that pulls the change of legal position of participants of relations in the field of providing of informative safety, or influence on national informative environment.

Legal forms are suggested to classify on edition of normative and individual acts on questions realization of public policy in the field of providing of informative safety and fianc es of other legally meaningful actions, that is related to the informative relations. Description over is brought each of forms. Attention is accented on that among the realization measures of legal influence on the sphere of providing of informative safety, administrative responsibility occupies one of main places next to responsibility criminal, as a considerable volume of public relations embraces sufficiently in informative sphere.

Reasonably, that practical efficiency of legal forms of government control in the field of informative safety depends on the level of professional preparation of workers of organs of state administration, to the competence of that realization of the imperious operating belongs under the aim of providing of informative safety of Ukraine. It is noticed that maintenance of legal forms of government control in the field of providing of informative safety must always answer the level of technical development of facilities, methods and methods of trenching upon a national informative environment.

Key words: Ukraine, information, legal forms of government control, function, public policy, informative safety, informative sovereignty, administrative responsibility. 